\title{
LOCAL REFORMERS AND THE SEARCH FOR CHANGE: THE EMERGENCE OF SALAFISM IN BALE, ETHIOPIA
}

\author{
Terje Østebø
}

It was not the regular khutba (Friday sermon), it was not a part of the weekly programme, and it was not announced to the congregation. Instead, it was an unprompted move as Sheikh Abubakr Muhammed rose to his feet and started to speak this Friday in 1971. His words could not be misunderstood: 'The awlia [saints] cannot bring you children, the awlia are dead. If you call a dead man, he will not answer. You say that the awlia are close to Allah and that they can bring your prayers to Allah. But these are all dead.'

The speech, as recorded here by one of the attendees, immediately sparked feelings of anger and outrage. It was made in the Nur mosque, the only mosque in the town of Robe in Bale (south-east Ethiopia); and it was the first time someone had attacked the existing practices publicly in such a clear and direct manner. Those defending the existing practices swiftly organized a broad front against Sheikh Abubakr Muhammed. As tensions increased in the months that followed, repeated attempts were made to force Sheikh Abubakr to retract his statements yet they were all in vain. His opponents rallied behind a certain Hajj Adam Sado, a local dignitary, former qadi (Islamic judge), and a highly respected figure within the Oromo society of Bale. Sheikh Abubakr had his supporters, a rather diversified group of less than forty individuals. Several meetings were held, in which emotions ran high and sober arguments had to yield to mutual insults. As the conflict sharpened, people were told to discontinue their relations with Sheikh Abubakr and his associates, not to greet them, and to refrain from attending their or their families' funerals. Some informants even claim that the people were encouraged to kill them. Inevitably, the conflict caught the attention of the local government and the governor, General Jagama Kello, summoned the two parties to Goba, the region's capital at the time. After listening to their arguments, the general decided to arrange a larger meeting, inviting all the involved parties. Attended by more than 400 people, including both supporters of the rival parties and curious spectators, the meeting is remembered as a major event of that time. Expectations ran high, and both parties assiduously prepared and mobilized support for their cases. The discussion revolved largely around two main issues: the pilgrimage to the shrine of Sheikh Hussein and the celebration of mawlid al-Nabi (the Prophet's birthday). Speaking for the Salafi party, Sheikh Abubakr made fierce attacks on the existing practices, arguing that they were irreconcilable

TERJE ØSTEBØ received his PhD in History of Religions from Stockholm University. He is currently Assistant Professor at the Center for African Studies and Department of Religion, University of Florida. He has undertaken extensive field research in Ethiopia and his latest book, Localising Salafism: religious change among Oromo Muslims in Bale, Ethiopia, will be published by Brill in 2011. Email: ostebo@ufl.edu 
with Islam. The other party had brought prominent figures from the locality, all voicing an unyielding defence of them.

Sheikh Abubakr Muhammed, often referred to as sheikh-mufti, is currently in his eighties. He is still frequently mentioned in every corner of the region as the one relentlessly purging Islam in Bale from 'unlawful innovations'. Whereas the nature of the new teaching in itself generated hostile reactions, Sheikh Abubakr's character was certainly not an appeasing factor. Those close to him describe him as a stubborn, hot-tempered man with a wilful personality. Bold and with little or no regard for others' opinions of him, his direct and sometimes insulting approach often sparked hostilities which augmented the tensions.

Sheikh Abubakr was obviously not singlehandedly responsible for the emergence of what I call the Salafi movement, or the 'Whahhabis' as it is referred to locally. ${ }^{1}$ The rapid expansion of Salafism during the 1990s has generated the assumption that this is a recent phenomenon; it has also produced rather shallow understandings and evaluative presumptions. Salafism is often seen as a representation of 'foreign and radical' Islam, unfitting for the Ethiopian context, enforced upon the local Muslims, and clearly distinct from the more tolerant 'local' Islam. ${ }^{2}$ This contribution, which discusses the short yet formative period from the early 1960 s to 1974 , will demonstrate the invalidity of such a perception, and offers fresh empirical data on the initial emergence of Salafism in the region of Bale (see map, Figure 1). ${ }^{3}$

A major argument is that framing the arrival of Salafism in a global/local dichotomy, viewing it as a movement arriving from an abstract 'outside' into an inherently 'traditional' locality is an insufficient approach. Instead, there is an urgent need to identify the specifics of the actual context from where such currents are carried, the conditions of the context in which they arrive, and to concretize and historicize the very interactions across local boundaries which enable the introduction of these new currents. This entails the investigation of the relevant factors facilitating the transcendence of the movement beyond its 'original' locality, as well as analysing who were involved in this process. As I will demonstrate in the following, the emergence of Salafism in Bale was largely facilitated by structural changes on both sides of the Red Sea, which both enabled the emergence of new groups of actors and increased inter-local interactions. Seeing structures as temporarily and spatially situated and as having no meaning except in relation to actors, I apply an actor-centred approach for understanding processes of change, and argue, moreover, for the need to recognize the multiplicity, transposability, and intersection of structures (Sewel 1992). This allows us to view the structures not as fixed and homologous and, moreover, to recognize how

\footnotetext{
${ }^{1}$ The word Salafi stems from the Arabic al-salaf al-salih, 'the pious ancestor', and relates usually to what is perceived as the authentic Islam. In this case it refers to the particular teaching of Muhammed ibn Abd al-Wahhab, and should not be confused with the nineteenth-century Egyptian Salafiyya movement.

${ }^{2}$ For more nuanced studies on Salafism in the areas of Wollo, Addis Ababa, Harar and Jimma, see, respectively, Abbink (2007), Bauer Oumer (2006), Desplat (2005) and Ishihara (1996).

${ }^{3}$ Bale is located in the Oromia Regional State and is today one of the strongholds of Salafism in Ethiopia. The material for this contribution was collected during an extensive fieldwork during 2005-2007, and is largely drawn from oral sources. Altogether, I conducted 257 interviews with 119 different informants.
} 


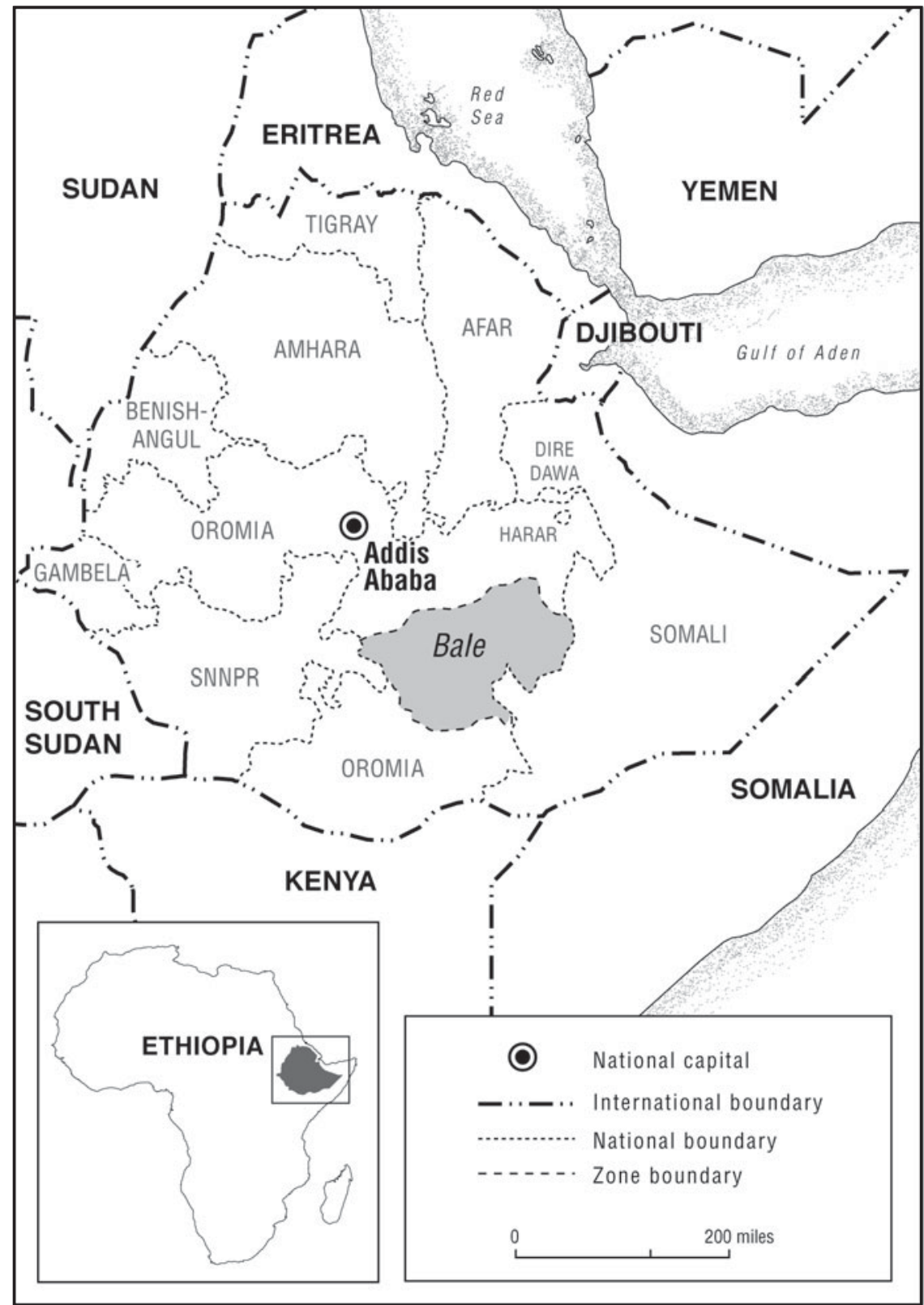

FIGURE 1 Map of Bale in Ethiopia 
actors, understood both collectively and individually (Hindess 1986), with transformative and reflective capacities, are able to manoeuvre within this structural complexity, and to accommodate currents for change. A major aim of this contribution is to demonstrate that the introduction of Salafism in Bale was embodied in indigenous agents who, though structurally situated, through conscious agency prepared, elaborated, maintained, and resisted the movement for reform. Also important is to show that this process of reform, with all its complexity, was not played out in the dialectics between two equally homogeneous groups of reformers and traditionalists, but entailed compound negotiations in which a diversified body of actors, having their own preferences and views, were deeply involved in the accommodation, appropriation and localization of this movement.

\section{THE TOPOGRAPHY OF ISLAM IN BALE}

While the initial arrival of Islam in Bale dates back to the medieval Bale Sultanate, the Oromo expansions into the area by the middle of the sixteenth century radically transformed the religious and ethnic landscape. ${ }^{4}$ The pastoralist and clan-based Oromo, arriving from the south, were socially structured according to the relatively egalitarian age-grade system of the gadaa and religiously through their Waaqanna religion. The existing Muslim population was either assimilated into the Oromo clans or pushed out of the region, causing a significant decline of Islam in Bale.

Developments from the late eighteenth century brought radical changes to the religious and socio-political setting in Bale. In a revival greatly influenced by processes of Islamization of the Oromo in the area of Hararge, north of Bale, and ensuing interaction with these developments, Islam returned. This has to be seen in relation to the general Sufi revival in the late eighteenth century, gradually being moulded within the localities of south-eastern Ethiopia. The main Sufi turuq never played any major role, and neither was there a development of any translocal identity of affiliation with the different brotherhoods. Rather, Sufism was associated with particular local shrines, with the shrine of Sheikh Hussein as the most prominent. While the figure of Sheikh Hussein is presumed to date back to the thirteenth century, the pilgrimage to the shrine, or muиda as it was referred to locally, was restored by Sheikh Muhammed Tilma Tilmo and Sheikh Abbas at the end of the eighteenth century, becoming crucial for the expansion of Islam in Bale. It brought the Oromo clans into contact with the shrine, making it a focal point in their religious universe. As the conversion of the Oromo was characterized by a gradual accommodation to the new faith, with the infusion of pre-Islamic Oromo elements into Islam, the pilgrimage came to be an alternative to the declining veneration of the abbaa muиda - the Oromo religious figurehead located in the southern parts of Bale. ${ }^{5}$ Located in the northern part of

\footnotetext{
${ }^{4}$ For details on the Bale sultanate, see Braukämper (2002: 76ff.) and for a general discussion on the history of Islam in Bale, see Østebø $(2005 ; 2008)$.

${ }^{5}$ For details on the pilgrimage to Sheikh Hussein, see Østebø (2008: 100ff.) and Braükamper (2002). For details on abbaa muиda, see Knutsson (1967: 144).
} 
Bale, the shrine attracted a large body of pilgrims from a wide geographical radius.

An intrinsic aspect of the rituals performed at the shrine was the provision of the wareega (sacrifice). The actual meaning of wareega is to make a vow, and the ritual consisted of three elements: the vow, the public confession of the vow, and the sacrifice. By making a vow, the confessant entered into a contract with the saint, promising to bring a sacrifice upon the fulfilment of his or her request. ${ }^{6}$ This could be either in cash or kind, for which the pilgrim in return received blessings practically experienced in the form of rain, abundance of food, prosperity, the well-being of the livestock, and the fertility of women. Authority at the shrine was held by the descendants of Sheikh Muhammed Tilma Tilmo and by the community of the darga at Dirre Sheikh Hussein, the village adjoining the shrine. Seen to have a mediating ability through their possession of karaama, ${ }^{7}$ they were highly respected and feared by the general population.

The recent Islamization of the Oromo and the relative isolation of Bale (traditionally the pastoralist Oromo undertook little long-distance trade), which produced this localized Islamic universe, clearly impinged on the development of Islamic scholarship. Until the early twentieth century there were hardly any ulama (Islamic scholars) in Bale, and the few of any repute were all immigrants from Wollo and Harar. It was not until the Italian period (1936-42) that a group of indigenous ulama emerged. Travels in search of religious knowledge increased during this period and centres for learning appeared, yet only a few could offer teaching at a higher level. The subjects taught were mainly fiqh (Islamic jurisprudence) according to the Shafi'ite school of law, with occasional teaching of nawhi (Arabic grammar). Books were a scarce commodity, and in contrast to other areas in Ethiopia, like Wollo, Harar, Jimma, and Arsi where the ulama composed their own religious texts, there are no traces of such activities in Bale. A much broader category was the Qur'anic teachers, scattered around in the rural areas. These figures had only rudimentary knowledge of Islamic scholarship and Arabic, and were combining teaching with esoteric activities. The production of and trade in amulets, along with fortune-telling founded upon Islamic numerology, provided a major part of their income. The consumption of these amulets, where pieces of paper with writings from the Qur'an were kept in the house, worn as ornaments, or eaten, reveals that the word, in its physical sense, was perceived to have protective and curative effects. A situation of 'linguistic inequality' (Bourdieu 1993), in which the people had limited access to the scriptures and where reading remained restricted to the hierarchy of religious specialists, produced circumstances where the word was held in great reverence - and regarded as embedded with mystical power:

By Shaya there was ... a big stone and a tree.... My grandfather used to sit by this stone reading the Qur'an. He didn't teach, but only read the Qur'an to himself. He was a learned man and the people thought that it was the karaama that had taught him to read.

\footnotetext{
${ }^{6}$ This could be characterized as a system of 'delayed exchange' in the sense that the venerator brings the offering after the request has been fulfilled (Pankhurst 1994: 935).

${ }^{7}$ While karaama in Arabic usually signifies miracles performed by those who possess baraka, the word is commonly used in Bale as the very ability or power to perform miracles.
} 
In addition, the Qur'an was also said to have karaama. It was like the Qur'an and prayer were magical things. They [the people] believed that if one person in the village prayed, that would be enough - he would pray for them also. ${ }^{8}$

As indicated by this informant, there was only a limited compliance with Islam's 'official' obligatory requirements among the general population. Whereas the fast was observed, there were only a few who prayed regularly. Instead, their practice of Islam revolved around the celebration of mawlid al-Nabi, mortuary rituals, and the veneration of Sheikh Hussein. Mosques were found in some of the major towns, while being virtually non-existent in the rural areas. The status of the shrines perceived as sacred spaces also generated a distinct notion of trepidation, manifested in the fear of the religious authorities. While there was a widespread belief that offerings would be exchanged with blessing (eebaa), there was, at the same time, a distinct fear of the guardians' ability to curse (abaarsuu) people at will (Andrzejewski 1972: 9). It was said, for example, that 'if a Shaykh passed the night in a particular house, the family head should give the Shaykh a cow, sheep or a certain amount of grain to get his blessing'. Failing to do so was believed to 'result in [a] catastrophe' (Aman Seifedin 1987: 25). A cursed person was one who would be 'excluded from blessings, prayers and greeting', and 'treated as if he was dead' (Baxter 1990: 238). He or she would be denied any relations with any member of the family, clan, or society.

The incorporation of Bale into the expanding Ethiopian kingdom in the late nineteenth century and subsequent developments during the twentieth century had lasting impacts on the region. Socio-politically, the introduction of a feudal structure with power transferred to Amhara administrators meant the final blow to the gadaa system. In economic terms, a new property regime was introduced with land taken over by Amhara landlords and the larger population reduced to tenants and tax-paying subjects. However, a system of indirect rule, with the appointment of subordinate balabats (local chiefs) and the commoditization of land, also paved the way for Oromo landlords, emerging as the new Oromo elite. This elite played an important role in maintaining the continuity of earlier structures, in mediating between the people and the new rulers, and in creating a situation where authority was hierarchically structured according to genealogy, age, formal positions and wealth.

The pax Amharica brought by the conquest, subsequent structural changes, and improvement of infrastructure were important for the expansion of trade and increased inter-local interactions. At the beginning of the twentieth century trade in Bale was controlled by non-Oromo and Yemeni traders. The Yemenis represented the largest group of expatriate traders in Ethiopia, arriving in Bale from around 1910 and establishing intimate relations with the Oromo-learning the local language, marrying local women and, moreover, employing locals in their businesses. ${ }^{9}$ Political and economic reforms from the latter part of the 1940s - the formation of a bureaucratized state apparatus and the streamlining of taxcollecting procedures - subsequently led to an increase of taxation of land, to the

\footnotetext{
${ }^{8}$ Oral interview, 15 August 2005.

${ }^{9}$ For general discussion of the Yemeni community in Ethiopia, see Hussein Ahmed (1997), Manger (2006) and Samson Abebe Bezabeh (2008).
} 
expansion of a money-based economy and to perception of land as a privately owned commodity (Gebru Tareke 1977: 249). The immigration of Christian Orthodox Oromo from the northern parts of Shoa into Bale from the 1950s accelerated this development. ${ }^{10}$ Already accustomed to an agricultural lifestyle, they soon engaged in land transactions, contributing to a large-scale and rapid expansion of the agricultural economy in Bale; this in turn led to a surplus of agricultural products, increased the relevance of local markets, accelerated urbanization, and enhanced translocal trade (Knutsson 1969: 91ff.; Blackhurst 1980: 58ff.). This all paved the way for the emergence of a new group of Muslim Oromo merchants in Bale. ${ }^{11}$ Most of them set up their businesses in the town of Robe, strategically located at the junction between Goba and the eastern and southern lowlands. The development of infrastructure commencing during the Italian period (1936-42) enhanced their communication with the surrounding localities - with Hararge, Arsi and with Addis Ababa. The construction of the first all-weather road connecting Bale to the central parts of Ethiopia in 1962, with the start of a bus service the following year, was a further advance.

The emergence of this group of merchants added a new dimension to the multiplicity of structures in Bale. Most of them were migrants from the rural parts of the central highlands, and urban migration was an important factor distancing them physically and culturally from the social pressure of clan and kin. They constituted a new entity, different from the rural- and clan-based Oromo society, and by gradually accumulating a certain degree of wealth, they attained the status of a highly respected group. Improved infrastructure which contributed to blurring spatial and symbolic boundaries opened up a new space, and shifted the merchants' orientations beyond the immediate locality. Increased inter-local interactions were thus instrumental in creating awareness of currents flowing at that time, and facilitating the arrival of these in Bale. Being at the forefront in transcending local boundaries, these merchants were to play a significant role in the religious drama about to unfold.

\section{REFORM AND INTERACTING LOCALITIES}

Meanwhile, the town of Harar north of Bale had already seen some changes in the religious sphere. These changes were the result of the arrival of a new teaching arriving from the Arabian Peninsula, and directly linked to an increase of pilgrims crossing the Red Sea during the Italian occupation. The Italians, seeking to legitimize their colonial project in the eyes of the Saudis, were actively encouraging and facilitating the pilgrimage to the holy cities (Erlich 2007: 39ff.). They provided funds covering the pilgrims' expenses, constructed guesthouses and a

\footnotetext{
${ }^{10}$ The majority of the Shoa Oromo came from northern Shoa (north of Addis Ababa). Lack of land and harsh treatment from the local nobility in Shoa forced them to migrate to the more fertile areas of southern Ethiopia. Being Orthodox Christians and newcomers to the area, they came to constitute a group caught between the Amhara rulers and the Oromo Muslims. For more details, see Blackhurst $(1974 ; 1980)$.

${ }^{11}$ The most important were Ahmado Kabir Faqi (1947), Hajji Korme Kimo (1947), Hajji Aman Hassan (1948), Hajji Kabir Abda (1948), and Hajji Abadir Hussein (1952).
} 
dispensary in Mecca to enhance the well-being of the Ethiopian pilgrims, and established bus connections to Massawa, where ships would take the pilgrims across the Red Sea (Temam Haji 2002: 48). ${ }^{12}$ Aiming at securing the support of the Muslim population against the Christian-dominated political elite, the Italian colonial administration issued a policy favouring the Muslims, who in turn saw the occupation as alleviating the existing situation of alienation and marginalization and as creating an opportunity to gain parity with the Christians. Their colonial experience was thus not seen as having a devastating impact on inherent structures, but was, according to one informant, a period when 'ijaa bannaanee' (we opened our eyes) - referring to the manner in which the Italian period brought Ethiopia's Muslims closer to the wider world of Islam (Temam Haji 2002).

The establishment of the Saudi Arabian kingdom in 1932 and the religiopolitical developments in the Hijaz obviously had a clear impact on the pilgrims arriving from Ethiopia. The efforts made by the new Saudi rulers to improve the administration of the two holy cities not only proved conducive to the pilgrimage, but also affected the pilgrims' religious perceptions. Inspired by the teaching of Muhammed ibn Abd al-Wahhab (1703-92), the Saudi Salafis were disseminating ideas which denounced pilgrimages to shrines, veneration of Muslim 'saints', and rituals performed at the graves as unlawful innovations. While critique of shrine veneration and 'grave worships' represents a longer genre within fiqh (Fierro 1992), the Salafis' strict understanding of tawhid (divine unicity or oneness), as captured in Abd al-Wahhab's concept of tawhid uluhiyya, gave rise to a demarcated understanding of what were to be considered bida (innovations). ${ }^{13}$ Not only did this lead to the rejection of pilgrimage to shrines and rituals performed in conjunction with tombs; it also led to a condemnation of tawassul (intercession) and of general practices associated with Sufism. Through al-dawa ila al-tawhid (the call to the doctrine of the oneness of God) the Salafis' aim was to call Muslims to the pure Islam. ${ }^{14}$

Whereas Salafism made an early imprint on the Muslim community in Harar, the Oromo of Hararge played a far more important role in the expansion of Salafism to other parts of south-eastern Ethiopia. This was directly connected to the expansion of khat as a cash crop in Hararge, since Oromo involvement in the production and trade of these narcotic leaves provided them with the resources to perform the hajj. ${ }^{15}$ Many spent time in the Hijaz studying the Salafi doctrines, and upon their return actively disseminated the new ideas among their kinsmen and

\footnotetext{
${ }^{12}$ In contrast to before the occupation, when only eleven Ethiopians left for pilgrimage (1933), the number rose to somewhere between 1,600 and 1,900 in 1936 (Erlich 2007: 73ff.).

${ }^{13}$ For remarks on the concept of tawhid in relation to the Salafi perception of unlawful practices, see Peskes (1999).

${ }^{14}$ For works on the life of Abd al-Wahhab, see for example Delong-Bas (2004) and Cook (1992); for works on Abd al-Wahhab's teaching, see Delong-Bas (2004); for studies on the ideological and political developments of Saudi Arabia, see for example Steinberg (2002), Commins (2006), Kechichian (1986), Piscatori (1983) and the volume edited by Al-Rasheed (2008); for the history of Saudi Arabia, see Al-Rasheed (2002), Vassiliev (2000) and Kostiner (1993).

${ }^{15}$ This is substantiated by the findings of Ezekiel Gebissa (2004) who, in an enlightening study on the development of khat production and consumption, amply demonstrates how the Oromo were involved in a trade prospering during the twentieth century.
} 
established centres for Salafi teaching in Hararge. ${ }^{16}$ From there the new ideas gradually spread to the neighbouring area of Arsi in the late 1950s, and to Bale in the 1960s.

\section{The merchants in Robe}

The group of merchants in Robe gradually developed into a separate religious category. Regularly observing each of the mandatory daily prayers and refraining from participating in the religious practices of their contemporaries, their display of piety added to their distinctiveness as there were few others of their age attending the prayer sessions in the mosque. At the same time, they were becoming increasingly uncomfortable with certain aspects of the rituals during the celebrations of the mawlid al-Nabi and the pilgrimage to Sheikh Hussein.

At the shrines, the wareega was an intrinsic part of the Oromo prayer economy. It constituted the only source of income for the guardians at the shrine, who would redistribute parts of the offerings as alms to the needy. A pilgrim with even a minimum of wealth was obliged to contribute in either cash or kind, which in turn would be redistributed as sadaqa (the voluntary giving of alms) to the poor. Similar practices were also performed during the celebration of mawlid al-Nabi, as well as during funerals and the subsequent prescribed period of mourning-all entailing lavish feasting. The deteriorating economic situation during the 1950s and 1960s, with heavy tax burdens and confiscation of land, led to an increase in the number of pilgrims and enhanced the relevance of alms. At the same time, the expansion of a money-based economy paved the way for a commoditization of gifts offered at the shrine. It meant that the wareega in the form of cash gained more importance, which in turn led to feuding among the shrine's guardians.

It was in particular this latter development which caused the merchants to react. Leading members of the group were becoming increasingly wary about the existing practices: 'When I went to Dirre [Sheikh Hussein] and saw the way of the people there, I didn't like it. I understood that their [the guardians'] only motive was to take the money from the people. ${ }^{17}$ Such attitudes were becoming formative for the rest of the merchants, leading them to start accusing the guardians of the shrine of shunning honest labour, maintaining a pattern of economic dependency through the offerings, and exploiting the poor. As upwardly mobile and ambitious-where each man had the responsibility of providing for himself - the merchants were in contrast underscoring hard work, economic selfreliance and modesty as key virtues. Excessive expenditure and the lavish feasting connected to the religious rituals were consequently ardently admonished.

It would, however, be misleading to think of the merchants' attitudes as an expression of niggardliness. Rather, their wealth was shared and spent for the reinforcement of Islam: through public endowment in financing an alternative religious infrastructure - first the construction of the Nur mosque, as Robe's first

\footnotetext{
${ }^{16}$ Important sites were the villages of Balbaletti and Fadis, where figures such as Sheikh Umar Balbaletti and Sheikh Abdallah Tuqo, respectively, were teaching. Sheikh Abdallah Tuqo, who had studied in Mecca, is by some informants claimed to be the main disseminator of Salafism among the Oromo in Hararge, a claim that is substantiated by his early involvement in conflicts with the local religious leaders, subsequently leading to his arrest and imprisonment.

${ }^{17}$ Oral interview, 18 August 2005.
} 
mosque in 1959, and an adjacent madrasa (Islamic school). ${ }^{18}$ In 1963 the merchants took the initiative in creating a jamaa (congregational fellowship) in Nur mosque, where they gathered for the study of the holy texts. This step became crucial for framing their critical attitudes within a broader doctrinal narrative. Not only were the existing religious practices seen as deviant from the Islamic message of social justice, but their emphasis on each man's responsibility in earthly matters was moreover brought into accord with a notion that ruled out the possibility of intercession for man with God. This consequently led them to question the efficacy of the shrine, the legitimacy of the pilgrimage, and to a reinterpretation of the opposing concepts of tawhid and shirk (associating other beings with God). Pivotal in this ideological development was the appointment of Sheikh Muhammed Hajji Mustafa as qadi of Bale in $1963 .{ }^{19}$ Educated at al-Azhar University, he relentlessly yet cautiously criticized the existing religious practices and contributed much in shaping the views of the merchants. Furthermore, in 1964, the merchants were joined by a certain Sheikh Muhammed-Amin Chaffa. Originally from Arsi, he had pursued his religious education in Hararge, where he became familiar with the Salafi doctrines. After completing his studies, Sheikh Muhammed-Amin Chaffa moved to Bale and established himself as a merchant in Robe. He refrained from teaching in the traditional way, but assumed the role of the main leader in the jamaa, where he guided the others through the scrutiny of the religious texts. Being an explicit adherent of Salafism, he nevertheless applied a tactical approach when disseminating such views within the locality - restricting the dawa (call) activities to private discussions.

Similar connections between mercantile activities and emerging religious reform have been noted by writers in other parts of Africa. In 1959 Trimingham wrote about the 'urban mind' of the Muslim merchant, arguing that he had a more 'individualistic and wide-visioned' character than his rural co-religionist (1959: 25). Elaborating on this, Lansine Kaba later claimed that the emergence of Islamic reform was accompanied by the rise of 'an individualist ethic' (1974: 70). ${ }^{20}$ While one should be careful not to suggest overly rigid causal links framed within a Weberian perspective, the intersection between merchants and religious reform does constitute an important aspect in need of further investigation. ${ }^{21}$ In any case, the views and attitudes of the merchants in Robe clearly illustrate the structural multiplicity and dynamics existing in Bale. It shows how this allowed for incongruent perceptions to coexist within a locality, and how certain segments of it would be more prone to challenge the widely accepted religious universe. Living closely together by the market place, where the mosque was also located, these merchants came to develop quite intimate relations, exercise a certain degree

\footnotetext{
${ }^{18}$ This madrasa was the predecessor to the Salafiyyah Madrasa established in 1976.

${ }^{19}$ Originally from Dirre Dawa in Hararge, Sheikh Muhammed Hajji Mustafa stayed in Bale as a qadi until 1969, before moving to Addis Ababa and assuming a teaching position in the alAnwar mosque. I have not been able to obtain biographical details of his further career, but according to local sources from Bale he was killed by an accidental shot in Addis Ababa a few years after he left Bale.

${ }^{20}$ See also Umar (1993: 176ff.); Masquelier (1999: 222); Brenner (2001: 67, 148ff.).

${ }^{21}$ A stringent Weberian perspective is noticeable in Geertz's (1963) and Mulyadi's (2006) writings about Indonesian Islam; the latter unambiguously claims that mercantile reformers were driven by a 'Calvinist type of ethic' (Mulyadi 2006: 203).
} 
of social pressure on each other, and share, as a result, a critical outlook towards the religious practices of their coreligionists.

\section{The journey of the eighty}

Parallel to this, an event in 1962 which I have labelled the 'journey of the eighty' was to become decisive for redirecting those in search of religious education, spatially as well as ideologically. It was pivotal in boosting contacts between Saudi Arabia and Bale, and in producing an explicit Salafi imprint on the process of religious reform.

The journey of the eighty was at the outset a pilgrimage made by young men, largely from Bale and Arsi, to Mecca. They did not constitute an organized group, but were individuals sharing the intention to perform the hajj. When the time of the pilgrimage approached, they started their journey eastwards - by foot and by public transportation. Arriving in Djibouti, the group had grown to eighty persons, and from there they headed across the Red Sea in two boats.

We went to Jijiga and stayed three days there. From there we went north to Goronka; that was on the border to Somalia. All the way we went on foot, but from Tullu Guled we got transport. We were five persons; three from Arsi.... We had a letter asking the people to support us....We had got some support at Macara, where we also sold some coffee-getting income. Also, during Ramadan in Hargeisa we got zakat from the people. The transport from Djibouti was cheap at that time. When we reached Yemen, we didn't go straight to Saudi. We were on our way, but we changed our minds; we wanted to go to Lahej. There we planned to work for some time. We wanted to save money and go by boat to Saudi. But instead we went to Saudi on foot. It took us twenty days to reach the border and twenty-five days again. We went by car to Tahif [At Ta'if]. ${ }^{22}$

Their arrival in Saudi Arabia coincided with developments within this context which would become pivotal for the story of reform in Bale, as well as for the dissemination of Salafism in Africa in general. During the 1950s the Saudi Arabian kingdom felt increasingly challenged by General Abd al-Nasser, who assumed power in Egypt in 1952. His socialist-inspired ideology, Egypt's connections to the Soviet Union and, in particular, its involvement in Yemen's civil war (1962-70) were viewed as not only repudiating the power balance in the Arab world, but also as weakening the position of Islam - causing the Saudis to pursue a policy aimed at strengthening their position in the Arab world (Al-Rasheed 2002: 116ff.). This included the creation of the Muslim World League (MWL) in 1962 and, of greater relevance here, the establishment of several institutions for higher Islamic learning designed to enhance Salafi influence in the Arab world and beyond (Sindi 1980: 186; Commins 2006: 152ff.). The first and most prominent of these, the Islamic University in Medina, accepted and housed a large number of foreign students. ${ }^{23}$

Those participating in the journey of the eighty did not anticipate spending more time in Saudi Arabia than the hajj required, but, due to the hardship of

\footnotetext{
${ }^{22}$ Oral interview, 3 July 2006.

${ }^{23}$ In fact, its regulations called for 75 per cent of its students to be recruited from overseas (Layish 1984: 36ff.; Commins 2006: 112).
} 
travelling, they arrived in Mecca too late for the pilgrimage. However, rather than returning home, they were offered the opportunity to pursue their religious studies in the newly established Saudi institutions for higher learning. Because of their lack of prior learning and proficiency in Arabic, most of them were obliged to spend three years at a lower-level institution, before being eligible to enrol either at the Um al-Kura in Mecca, which was specially designed to host non-Arabic speakers, or at the Islamic University in Medina. Tuition was free, and the scholarships offered by the Saudis covered all their expenses.

Among those participating in the journey of the eighty was Sheikh Abubakr Muhammed. A native of Shaya, a few kilometres west of Robe, where his father Muhammed Hussein had been the village's Qur'an teacher, he received his initial religious education in Bale before pursuing his studies in Arsi and then in Dirre Dawa (Hararge). Arriving in Saudi Arabia he did not enrol in any of the Islamic universities, but parted from the others and left for Abha in the region of Asir. There he remained under the guardianship of a certain Sheikh Abdallah Wabile until 1969, studying tafsir (commentary on the Qur'an) and the techniques of dawa.

Those from Bale who participated in the journey of the eighty were the first to attend higher Islamic education in Saudi Arabia, and as news about such possibilities reached Bale, an increasing number of Oromo Muslims crossed the Red Sea in search of knowledge during the 1960s and 1970s. Most of the prospective students stated pilgrimage as the reason for going and applied for entrance at the various universities after their arrival. The journey of the eighty was thus important in paving the way for others to come, and decisive for the direction of the process of reform in Bale.

\section{The development of a Salafi identity}

The initial process of religious change was inherently gradual and of a dialectical character. The merchants' critique of the existing practices was reciprocally deepened and elaborated by their increasing contacts with Salafism. Through their interactions with those in neighbouring areas, their ideological outlook was gradually framed within a Salafi narrative-yet without a conscious Salafi identity. The travels they made to Hararge, Arsi, or to the capital exposed them to - and soon led to their capture by - the Salafi scriptures. They developed great respect for the Salafi teachers in these neighbouring areas, who were well equipped with books and textual arguments, and rapidly and readily accepted their message. As one of my informants from Hararge put it: 'when these people from Bale were presented with a book by ibn Taymiyya where the cover read sheikh al-Islam, they immediately embraced it'. A pivotal reason for this immediate acceptance was their limited knowledge of the variety of Islamic scholarship. Only a few of the merchants had received religious education beyond Qur'anic schools during childhood, and being situated in a context with a restricted tradition of Islamic scholarship and in a reality dominated by a particular localized version of Islam, they were in no position to juxtapose the Salafi ideas with other scholarly traditions of Islam. Neither were they able to establish ideological links between this teaching and Abd al-Wahhab or Saudi Arabia. Salafism was by them rendered an integrated part of 'mainstream' Islamic 
theology, and the standard for the reformers' quest in rectifying religious practices and deepening Islamic piety among their compatriots.

From the latter part of the 1960s, the jamaa attracted new adherents, bringing the total number up to twenty-four members. They were at this time refraining from participating in the practices of their coreligionists, which included, above all, the pilgrimage and the offerings to the local shrines. Whereas they were actively discussing the issue of legitimate religious rituals, they were careful not to voice this in public and sought to entertain smooth relations with the rest of the society. Gradually, however, as tensions increased as a result of the expansion of Salafi ideas in the various localities in south-eastern Ethiopia, more clear-cut symbolic boundaries emerged - leading to a more demarcated Salafi identity and to what would become the Salafi movement in Bale.

A crucial factor for this was the forming of an alliance between the local merchants and the returnees from Saudi Arabia. First of all, this alliance made it possible for the Salafis to expound their doctrinal positions, in which the Saudieducated ulama were decisive in elaborating the Salafi teaching. Assuming leading positions in the Nur mosque and in the madrasa, the Salafi movement was provided with the needed space and the human resources for the propagation of the new ideas; it managed to secure control over religious knowledge, which consequently contributed to sustaining the new movement. ${ }^{24}$ Secondly, the alliance contained an important socio-economic dimension. The returnees constituted, like the merchants, a novel group within the socio-religious make-up of Bale, and found themselves in an insecure situation. Traditionally, the ulama, like other religious experts in Ethiopia, were entirely dependent on the benevolence of the people-earning their income by hosting students. The returnees from Saudi Arabia, ideologically dislocated from their locality, would obviously not benefit from such support. Not seeking recognition as conventional Qur'anic teachers nor hosting any students, they soon found themselves in a precarious economic situation, without any income-earning work. The support provided by the merchants, in the form of direct financial aid and indirectly through the merchants' efforts in financing an alternative religious infrastructure, salvaged the Salafi ulama from this situation. Particularly important was the madrasa, where the Salafi ulama could find jobs as teachers and make their own living. The alliance thus led to the reproduction of the socio-economic relationship between the religious experts and the laity, a relationship which emancipated the former from economic constraints and provided the latter with an elaborate ideological orientation. In this way a merger of emerging actors belonging to different social categories, and reciprocally affecting each other, became pivotal in maintaining and furthering the process of reform.

\section{ENCOUNTERING SALAFISM}

By the time of the meeting in Goba in 1972, the Salafis allegedly consisted of a diversified group of merchants, some few local ulama, and returnees from Saudi

\footnotetext{
${ }^{24}$ Staffed by graduates returning from Saudi Arabia, the teaching was organized in classrooms and structured through an explicit curriculum with a clear Salafi outlook.
} 
Arabia, all present at the meeting. The other and much larger party was represented by the main ulama and local Oromo dignitaries. A conspicuous aspect was the absence of the guardians of the shrines. My Salafi informants claimed that this was because they were unable to argue their case - being ignorant of Islamic scholarship and lacking any proficiency in Arabic. Although this may have been the case, another crucial aspect was that they looked upon themselves as set apart from the rest of the society. Drawing on sources of an esoteric nature in legitimizing this status, the role they played in managing the shrine's rituals, and the very nature of the shrine, situated them beyond the reach of objective scrutiny and doctrinal debate.

During the actual meeting, it was Sheikh Abubakr who voiced the Salafis' views, and reports do not mention much involvement of the other Salafis. He emphasized the notion of tawhid and argued that the pilgrimage to Sheikh Hussein was irreconcilable with this concept. Whereas there were recurring references to tawhid as a core idea, there are few indications, however, of any elaborate understandings of this concept. By contrast, the theological debate among the Salafis in Hararge was more 'sophisticated' and included a heated controversy over the understanding of Sure 20:5, describing God as sitting on a throne. ${ }^{25}$ Rather than expounding on the doctrinal maze, the early Salafis in Bale intrinsically linked the concept of tawhid to the condemnation of the shrine's practices as shirk. The general and immediate reaction to the attacks by those defending the existing practices was that of surprise: never before had they been forced to articulate the very sources sanctioning the legitimacy of their world. It had been sufficiently embodied in the Muslim rituals to which everybody adhered. The general population saw the Salafi ideas not only as denunciations of an established tradition, but also as an attack on their Muslim identity. What the Salafis were suggesting was that they were not really Muslims. Adding to this was the dimension of fear. As their religious identity was framed within the narratives of Sheikh Hussein, which as we have seen held a potential menace, this fear was also the basis for social pressure, and the pilgrimage as a defining collective ritual required the participation of all Muslims. Disregarding it could have severe consequences, and anyone who chose another way would face social isolation and mundane punishment. The power of the shrine and the guardians' capacity to cause malevolent retributions were thus powerful mechanisms securing continued adherence to the established practices.

Reviewing the points of view and arguments put forward during the meeting more closely, it becomes apparent that the responses to the new movement entailed a process of negotiation. Those involved, depending on their religious and social positioning within the locality, held different conceptions of the existing religious practices, and were, moreover, invoking different sources during the debate. The Oromo dignitaries and traditional elders made no references to Islam's written sources, but referred instead to aadaa (culture, way of life) and

\footnotetext{
${ }^{25}$ When the Salafis in Hararge argued for a literal interpretation of this verse, their opponents accused them of assigning anthropomorphic attributes to God. This theme, as well as the question of whether God has hands (Sure 38: 75) has been recurrent in controversies between Salafis and their opponents, which in turn illustrates the Salafi underscoring of a literal reading of the texts (Kaba 1974: 99ff.; Wiktorowicz 2006: 210-11).
} 
established traditions, claiming that the pilgrimage was an intrinsic part of their forefathers' culture, something which had been practised for generations. They presented the shrines as embedded in a mystical sphere, and, drawing on sources of an esoteric character, defended the rituals as the embodiment of divinely sanctioned practice. What the Salafis were bringing was a foreign teaching, they argued, alien to the Oromo culture and unsuitable for the people in Bale.

The attitudes of the local ulama were, however, of a more complex nature, and it is clear that they harboured an ambivalent attitude towards both the existing practices and the Salafi ideas. Their use of the term ziyara (pilgrimage, veneration of a holy person), rather than muuda, reveals that they construed the pilgrimage as somewhat distinguished from the Oromo traditions, and demonstrates that both the pilgrimage and the shrine itself were interpreted more in line with broader Sufi traditions. While they, on the one hand, unequivocally embraced the notion of the wali's interceding powers, they were, on the other hand, opposed to the elevation of Sheikh Hussein to a deity. They avoided participating in the most popularized rituals and remained critical of the offering of wareega, seen in the way they advised the pilgrims not to 'load their donkey' - that is, not to bring sacrifices to the shrine. ${ }^{26}$ However, even if this placed them in a middle position, it was the established socio-economic relationship which became decisive for their resistance to the emerging Salafi teaching. Entirely dependent on the benevolence of the people, with their income coming from the contributions of their students and from managing nikaa (marriage) and funeral ceremonies, this dependency made it imperative for the ulama to entertain a good relationship with their constituency, which in turn restricted their opportunities to question the existing religious practices. That would, as one informant tells us, interrupt the material foundation for their livelihood:

I myself didn't believe in Sheikh Hussein.... But I wanted to live in peace with the community and that is why I didn't oppose it. I had few students, and if I opposed the pilgrimage, I would lose them all; meaning I would lose my income. I couldn't have lived here, if I opposed it. ${ }^{27}$

The Salafis for their part referred exclusively to the scriptures of Islam, presented as the true heritage of Islam and the only valid sources for legitimizing religious practices. They sternly argued that the existing rituals were not sufficiently grounded in the scriptures, that they were drawn from false traditions, and that they consequently had to be rejected. It is not clear what passages from the Qur'an or which hadith they referred to, and one has to assume that the heated debate gave only limited room for a thorough exegesis of the scriptures.

Of particular importance was the direct connection made between the scriptures and knowledge based on a cognitive approach to the text - in clear accordance with the general ideas of Salafism - and which contributed to an altered conceptualization of the written word. Consumption of the scripture embodied in amulets was rendered blasphemous and simply memorizing and reciting the text was rendered insufficient; unlawful practices could not be avoided unless the

\footnotetext{
${ }^{26}$ Oral interview, 18 August 2005.

${ }^{27}$ Oral interview, 14 July 2005.
} 
believer acquired the necessary knowledge to do so. In other words, the text was to be read and understood. The enhanced significance of scripture among reform movements in Africa has often been related to processes of modernization and rationalization of society (Brenner 1993; 2001; Niezen 1991; Westerlund 1997). Rooted in a Weberian paradigm, and teleological in its essence, such a process has often been construed as inevitable - as a necessary decline of 'traditional' practices and the augmenting of 'rational' conceptualizations of reality. This perspective has been challenged by Benjamin Soares (2005: 3ff.), who claims that modernization and rationalization entail far more complex processes, and who argues that the specifics of the local social reality need to be carefully considered. In the locality of Bale, the altered conception of knowledge and scripture was clearly not a result of profiled processes of modernization and rationalization, but rather a result of the blurring of local boundaries. The expansion of translocal contacts had created a situation of increased availability of religious texts, and subsequently created space for different perceptions of the word.

The repeated references to scripture by the Salafis and their constant fretting about scriptural evidence forced the local ulama to formulate textual arguments to meet the Salafi charges. Yet the subsequent discourse over texts and understandings of texts would in turn augment their disagreements. Emphasis on scripture as the final authority led to a discourse not only about orthodoxy, but also about the legitimate sources of that orthodoxy - and to the drawing of a boundary between legitimate and illegitimate texts. As recorded by one of those present at the meeting, the opponents of the Salafis had chosen Sheikh Juneidin Oborra to speak for them. He was considered the leading scholar in Bale, yet as he rose to his feet and started to read from the scriptures, he was interrupted by Sheikh Muhammed Gishe:

We don't agree that this person should make a decision. The book he has is not a true book, it is not the Qur'an. If the judgment is based on the Qur'an, we will accept it. But if he cites that book we will not accept it. ${ }^{28}$

Not surprisingly, the first to be rejected were books on Islamic numerology and astrology, mawlid al-Nabi poems and the hagiography of Sheikh Hussein; the Rabi al-Kulub. ${ }^{29}$ Previously perceived and respected as part of the Islamic legacy, these texts were suddenly no longer valid. Not only were the Salafis demanding textual evidence for accepting established customs-going further, they were nullifying the very nature of these evidences. Another and somewhat curious issue was the surfacing of a disparate perception of the Qur'an. The Salafi preference for the written word was accompanied by the increase of printed Qur'ans, which because of the bright white printed paper soon were considered by the people to be different from the older handwritten Qur'ans - which due to the ageing of the paper had a reddish color. A subsequent dichotomy was established between the warra kitaaba diima (the people of the red book) and the warra kitaaba adii

\footnotetext{
${ }^{28}$ Oral interview, 10 August 2005.

${ }^{29}$ Rabi al-Qulub, which means the 'Springtime of the Hearts', is a collection of stories about Sheikh Hussein, first published Cairo in 1926/7. For an enlightening discussion of the text, see Gori (1997).
} 
(the people of white book), and it was widely believed that the book of the former was not the true Qur'an but rather a distortion of the divine message.

While one might assume that the success of a movement of reform making explicit references to the authoritative scriptures of Islam would depend on a developed textual tradition, my suggestion is that the lack of Islamic scholarship and a textual tradition in Bale augmented the process of change. At the outset, the relatively recent history of Islamic scholarship in Bale and the scarcity of ulama clearly restricted their ability to produce textually based arguments to counter the Salafi positions. Only a very few of the ulama were affiliated to any tariqa (Sufi brotherhood), and a general absence of Sufi literature had produced a situation in which there was little or no elaborate thinking on the issues of shrines, pilgrimages, and tawussal. ${ }^{30}$ It is clear that their inability to provide textual support for their position - in contrast to the Salafis' constant references to the scriptures-enfeebled the resistance to the new teaching, and weakened their status in the eyes of the wider audience. By contrast, areas like Wollo and Harar were far better prepared to resist the Salafi dogmas. Inserted in a long history of Islam which had produced a strong class of ulama, hosting a tradition of indigenous Islamic literacy, and possessing more elaborate knowledge of Sufi theological positions, Muslims of these areas were more aware of existing doctrinal differences and thus better prepared to evaluate the Salafi teaching critically.

\section{CONCLUSION}

The meeting in Goba did not lead to any agreement, nor did it bring the two parties closer together. It constituted, however, a watershed in the history of Salafism in Bale-providing the Salafis with an official recognition that legitimized their presence in Bale, and enabling them to propagate their views among the people freely. Sheikh Abubakr Muhammed's sermon and the meeting consequently came to represent the starting point of tensions which have characterized the religious landscape until today. Thus the short period discussed in this contribution constituted an important and formative period in the history of Salafism in Bale.

Reform was not something imposed on the local actors from the outside, but was a home-grown movement introduced, maintained, and appropriated by a diverse body of indigenous actors. It was embodied in merchants, religious scholars and students returning from Saudi Arabia - situated actors marked by discontent over existing practices and influenced by alternative currents. While socio-economic changes paved the way for these new groups of actors, reform was also made possible by developments in the area of communications which brought localities closer together and created space for novel discourses about religious practices and symbols. The actors were informed by ideas arriving from across the Red Sea, which in turn were moulded within the ethnic group of the Oromo; among those of Hararge, Arsi and Bale. Situated within a relatively

\footnotetext{
${ }^{30}$ Sheikh Juneidin Oborra, one of the main ulama in Bale, was initiated into the Rashadiyya order during his stay in Jimma, but was prohibited from issuing ijaza (certificates) to this order in Bale.
} 
similar cultural universe, these agents were arguably in a better position to disseminate the Salafi message in their respective localities. They were able to accentuate certain aspects of the teaching and to present it in a way that enhanced reception among the audience. Clearly, the new teaching sparked controversies, yet it is important to understand the advance of the reform movement as a complex process. Those adhering to and defending the existing rituals and symbols made reference both to local traditions and to a wider Islamic heritage, but harboured, at the same time, diversified conceptions and opinions. The process of reform was thus the sum of rounds of negotiations by actors actively engaged in shaping the future of their localized universe.

Two years after the meeting in 1972, Ethiopia experienced dramatic transformation through the Marxist revolution. The Salafi movement survived the coercive policy of the Derg regime, and re-emerged with renewed strength in the early 1990s. Salafism has since then gained ground as the dominant religious current in Bale, and has simultaneously made deep impacts on other localities in Ethiopia. As a movement it has become increasingly diversified and subject to internal fragmentation, yet it has also helped to pose questions on Islam's relation to the wider Ethiopian society. This complexity is by itself a strong imperative for the continued study of Salafism and Islamic reform in Ethiopia.

\section{ACKNOWLEDGEMENTS}

The article is based on the paper 'Religious change and Islam: the emergence of the Salafi movement in Bale, Ethiopia' presented at the 16th International Conference on Ethiopian Studies, Trondheim, 2007. I am grateful to Patrick Desplat, Marit Tolo Østebø and to Africa's anonymous reviewers for constructive criticism of earlier drafts.

\section{REFERENCES}

Abbink, J. (2007) 'Transformation of Islam and communal relations in Wallo, Ethiopia' in B. F. Soares and R. Otayek (eds), Islam and Muslim Politics in Africa. New York NY: Palgrave-Macmillan.

Al-Rasheed, M. (2002) A History of Saudi Arabia. Cambridge: Cambridge University Press.

(ed.) (2008) Kingdom without Borders: Saudi Arabia's political, religious and media frontiers. New York NY: Columbia University Press.

Aman Seifedin (1987) 'The Muslim Community of Gobba: 1890-1960'. BA thesis, Addis Ababa University.

Andrzejewski, B. W. (1972) 'Allusive diction in Galla hymns in praise of Sheikh Hussein of Bale', African Language Studies 13 (1): 1-31.

Bauer Oumer (2006) 'The Development of Islamic Propagation (Da'wa) in Addis Ababa and Its Surroundings'. MA thesis, Addis Ababa University.

Baxter, P. T. W. (1990) 'Oromo blessings and greetings' in A. Jacobson-Widding (ed.), The Creative Communion: African folk models of fertility and the regeneration of life. Stockholm: Almquist and Wiksell International. 
Blackhurst, H. (1974) 'A Community of Shoa Galla in Southern Ethiopia'. $\mathrm{PhD}$ thesis, University of Manchester.

- (1980) 'Ethnicity in southern Ethiopia: the general and the particular', Africa 50 (1): 55-65.

Bourdieu, P. (1993) Sociology in Question. London: Sage.

Braukämper, U. (2002) Islamic History and Culture in Southern Ethiopia: collected essays. Hamburg: Lit Verlag.

Brenner, L. (1993) 'Introduction: Muslim representations of unity and difference in the African discourse' in L. Brenner (ed.), Muslim Identity and Social Change in sub-Saharan Africa. Bloomington and Indianapolis IN: Indiana University Press.

- (2001) Controlling Knowledge: religion, power and schooling in a West African Muslim society. Bloomington and Indianapolis IN: Indiana University Press.

Commins, D. (2006) The Wahhabi Mission and Saudi Arabia. London: Tauris.

Cook, M. (1992) 'On the origin of Wahhabism', Journal of the Royal Asiatic Society of Great Britain and Ireland 2 (2): 191-202.

Delong-Bas, N. J. (2004) Wahhabi Islam: from revival and reform to global jihad. Oxford: Oxford University Press.

Desplat, P. (2005) 'The articulation of religious identities and their boundaries in Ethiopia: labelling differences and processes of contextualisations in Islam', Journal of Religion in Africa 35 (4): 482-505.

Erlich, H. (2007) Saudi Arabia and Ethiopia: Islam, Christianity, and politics entwined. Boulder $\mathrm{CO}$ and London: Lynne Rienner.

Ezekiel Gebissa (2004) Leaf of Allah: khat and agricultural transformation in Hararge, Ethiopia 1875-1991. Oxford: James Currey.

Fierro, M. (1992) 'The treatises against innovations', Islam 69 (2): 204-46.

Gebru Tareke (1977) 'Rural Protest in Ethiopia, 1941-1970: a study of three rebellions'. PhD thesis, Syracuse University.

Geertz, C. (1963) Peddlers and Princes: social change and economic modernization in two Indonesian towns. Chicago IL: University of Chicago Press.

Gori, A. (1997) 'First studies on the texts of Shaykh Husayn's hagiographies', Rivista Degli Studi Orientali 70 (1-2): 53-82.

Hindess, B. (1986) 'Actors and social relations' in M. L. Wordell and S. P. Turner (eds), Social Theory in Transition. London: Allen and Unwin.

Hussein Ahmed (1997) 'A brief note on the Yemeni Arabs in Ethiopia' in Proceedings of the 13th International Conference of Ethiopian Studies, Kyoto.

Ishihara, M. (1996) 'Textual analysis of a poetic verse in a Muslim Oromo society in Jimma area, southwestern Ethiopia', Senri Ethnological Studies 43: 207-32.

Kaba, L. (1974) The Wahhabiyya: Islamic reform and politics in French West Africa. Evanston IL: Northwestern University Press.

Kechichian, J. A. (1986) 'The role of the ulama in the politics of an Islamic state - the case of Saudi-Arabia', International Journal of Middle East Studies 18 (1): 53-71.

Knutsson, K. E. (1967) Authority and Change: the study of the kallu institution among the Macha Galla of Ethiopia. Göteborg: Etnografiska Museet. 
(1969) Dichotomization and integration: aspects of inter-ethnic relations in southern Ethiopia.' in F. Barth (ed.), Ethnic Groups and Boundaries: the social organization of cultural difference. Oslo: Universitetsforlaget.

Kostiner, J. (1993) The Making of Saudi Arabia: from chieftaincy to monarchical state. Oxford: Oxford University Press.

Layish, A. (1984) "Ulama" and politics in Saudi Arabia' in M. Heper and R. Israeli (eds), Islam and Politics in the Modern Middle East. New York: St Martin's Press.

Manger, L. (2006) 'Globalization on the African Horn: Yemenis in southern Somalia and Ethiopia' in R. Loimeier and R. Seesemann (eds), The Global Worlds of the Swahili: interfaces of Islam, identity and space in 19th and 20th-century East Africa. Berlin: Lit Verlag.

Masquelier, A. (1999) 'Debating Muslims, disputed practices: struggles for the realization of an alternative moral order in Niger' in J. Comaroff and J. L. Comaroff (eds), Civil Society and the Political Imagination in Africa. Chicago: University of Chicago Press.

Mulyadi, S. (2006) 'Max Weber's remarks on Islam: the protestant ethic among Muslim puritans', Islam and Christian-Muslim Relations 17 (2): 195-205.

Niezen, R. W. (1991) 'Hot literacy in cold societies: a comparative study of the sacred value of writing', Comparative Study of Society and History 33 (2): $225-54$.

Østebø, T. (2005) A History of Islam and Inter-Religious Relations in Bale, Ethiopia. Stockholm: Almquist and Wiksell International.

_ (2008) 'Localising Salafism: Religious Change among Oromo Muslims in Bale, Ethiopia'. PhD dissertation, Stockholm University.

Pankhurst, A. (1994) 'Reflections on pilgrimages in Ethiopia' in Proceedings of the 12th International Conference on Ethiopian Studies, East Lansing MI.

Peskes, E. (1999) 'The Wahhabiyya and Sufism' in F. De Jong and B. Radtke (eds), Islamic Mysticism Contested: thirteen centuries of controversies and polemics Leiden: Brill.

Piscatori, J. (1983) 'Ideological Politics in Saudi Arabia' in J. Piscatori (ed.), Islam in the Political Process. Cambridge: Cambridge University Press.

Samson Abebe Bezabeh (2008) 'Among People with History: a study of Yemeni diaspora and Ethiopian state interaction'. MPhil thesis, University of Bergen.

Sewel, W. H. Jr (1992) 'A theory of structure: dualism, agency, and transformation', American Journal of Sociology 98 (1): 1-29.

Sindi, A. M. (1980) 'King Faisal and Pan-Islamism' in W. A. Beling (ed.), King Faisal and the Modernisation of Saudi Arabia. London: Croom Helm.

Soares, B. F. (2005) Islam and the Prayer Economy: history and authority in a Malian town. Edinburgh: Ann Arbor.

Steinberg, G. (2002) Religion und Staat in Saudi-Arabien. Würtzburg: Egon.

Temam Haji (2002) 'Islam in Arsi, Southeast Ethiopia (ca. 1840-1974)'. MA thesis, Addis Ababa University.

Trimingham, S. J. (1959) Islam in West Africa. London: Clarendon.

Umar, M. S. (1993) 'Changing Islamic identity in Nigeria from the 1960 s to the 1980s: from Sufism to anti-Sufism' in L. Brenner (ed.), Muslim Identity and Social Change in sub-Saharan Africa. Bloomington and Indianapolis IN: Indiana University Press. 
Vassiliev, A. (2000) The History of Saudi Arabia. London: Saqi Books.

Westerlund, D. (1997) 'Reaction and action: accounting for the rise of Islamism' in D. Westerlund and E. E. Rosander (eds), African Islam and Islam in Africa. London: Hurst and Company.

Wiktorowicz, Q. (2006) 'Anatomy of the Salafi movement', Studies in Conflict and Terrorism 29 (3): 207-39.

\section{ABSTRACT}

Since 1991 Salafism has gained renewed strength in Ethiopia, spurred increased tensions within the Muslim community, and created concern among the Christian population. This contribution focuses on the early emergence of Salafism in the area of Bale, currently one of the movement's strongholds. It discusses its initial arrival in south-eastern Ethiopia, and pays particular attention to the developments in Bale during the 1960s. Challenging the notion that treats Islamic reform as seemingly homogeneous and as 'foreign' - distinctly separated from 'local' Islam - the contribution explores the arrival of the Salafi teaching from Saudi Arabia, and follows the process of reform embodied in an emerging group of local merchants and in graduates returning from studies in Saudi Arabia. The contribution highlights how socio-economic changes and developments of infrastructure facilitated the emergence of new groups of actors, transcending local boundaries and actively generating novel discourses about religious symbols and practices. It also demonstrates how a diversified body of situated actors was crucial for the appropriation and domestication of the Salafi message, and points to the trajectory of reform as a dialectical process of moulding that related such influences to the local context.

\section{RESUMÉ}

Depuis 1991, le salafisme connaît un regain de vitalité en Éthiopie, favorise une montée des tensions au sein de la communauté musulmane et suscite l'inquiétude au sein de la population chrétienne. Cet article examine l'émergence du salafisme dans la région de Bale, l'un des fiefs actuels du mouvement. Il évoque son arrivée dans le Sud-Est de l'Éthiopie et s'intéresse particulièrement à son évolution à Bale depuis les années 1960. Remettant en cause l'idée selon laquelle la réforme islamique serait homogène en apparence et étrangère, à savoir distincte de l'islam « local », l'article examine l'arrivée de l'enseignement salafiste d'Arabie Saoudite, et suit le processus de réforme incarné par un groupe émergent de marchands locaux et par de jeunes diplômés de retour d'études en Arabie Saoudite. L'article met en lumière la manière dont les changements socioéconomiques et les progrès d'infrastructure ont facilité l'émergence de nouveaux groupes de protagonistes, transcendant les frontières locales et générant activement des discours nouveaux sur les pratiques et les symboles religieux. Il démontre également le rôle essentiel d'un corps diversifié d'acteurs (situés) dans l'appropriation et la domestication du message salafiste, et décrit la trajectoire de la réforme comme un processus dialectique de modelage associant ces influences au contexte local. 